\title{
Recent seismogenic fault activity in a Late Quaternary closed-lake graben basin (Albacete, SE Spain)
}

\author{
M.A. Rodríguez-Pascua ${ }^{a}$, R. Pérez-López ${ }^{a}{ } *$, J.P. Calvo ${ }^{a}$, M.A. García del Cura ${ }^{b}$ \\ a Area de Riesgos Geológicos, IGME - Instituto Geológico y Minero de España, c/ Ríos Rosas 23, 28003, Madrid, Spain \\ b Laboratorio de Petrología Aplicada, Dpto. de Ciencias de la Tierra, Universidad de Alicante, CSIC - Apdo, 99-03080 Alicante, Spain
}

\begin{abstract}
A B S T R A C T

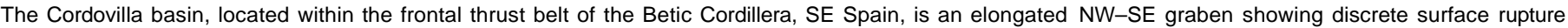

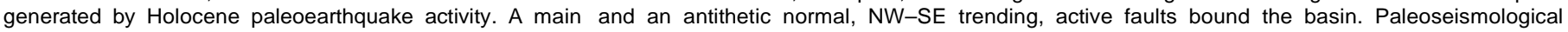

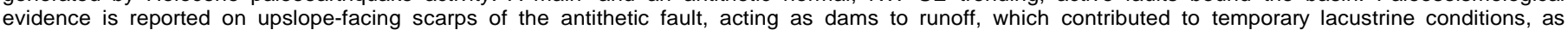

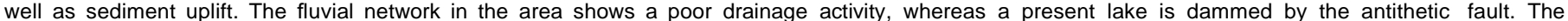

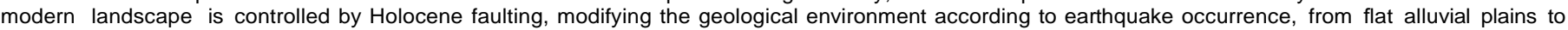

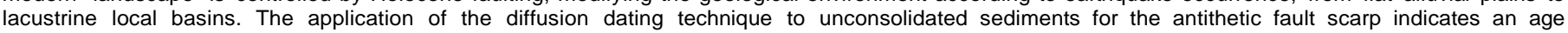

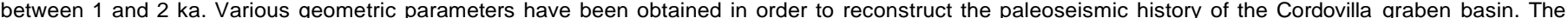

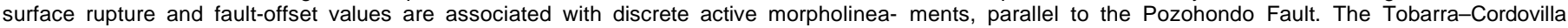

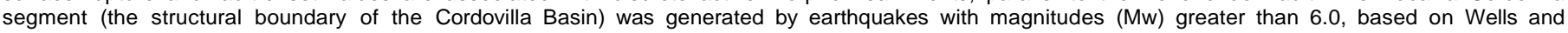
Coppersmith fault scarp relations.
\end{abstract}

Keywords: Active fault Graben basin, Diffusion equation, Paleoearthquake, Holocene, SE Spain

\section{Introduction}

Paleoseismic studies in active Quaternary basins have contributed to identifying a knowledge of the seismicity of the SE part of the Iberian Peninsula by identifying a number of strong to moderate-sized earthquakes (5 b M b 7), prior the historic period (pre-1400) (Santanach and Masana, 1999; Rodríguez-Pascua et al., 2003). Current seismic networks have recorded a few moderate size earthquakes $(\sim \mathrm{Mw} 6.0)$, both in the Iberian Peninsula and in the Maghreb area (Carreño et al., 1989; Stich et al., 2003). In addition, geological evidence from different parts of the Iberian Peninsula points to relevant fault activity during the Quaternary, associated with fault rupture lengths greater than $10 \mathrm{~km}$ (Silva et al., 1992, 1993; Masana, 1996; Martínez-Díaz, 1999; Rodríguez-Pascua et al., 2000, 2003; Martínez-Díaz et al., 2003). This assessment is based on various paleoseismic techniques such as, analysis of liquefaction structures and fluidization (Calvo et al., 1998; Rodríguez-Pascua et al., 2000),

\footnotetext{
* Corresponding author. Tel.: +34 913495786; fax: +34 913495834 . E-mail addresses: ma.rodriguez@igme.es, rbicoin@gmail.com (M.A. Rodríguez-Pascua) rperez.fcex@ceu.es (R.Pérez-López).
}

tectonic geomorphology and related fluvial network evolution (Silva et al., 1997, 2003), and trenching techniques used to reconstruct the evolution of colluvial and alluvial wedges associated with fault move- ment (Masana et al., 2005).

Seismicity in the Iberian Peninsula is related to the convergence between African and the Eurasian Plates and the relations to the Atlantic Mid-Ocean Ridge. The convergence generates a strike-slip regional stress field, with $S_{\mathrm{Hmax}}$ trending NW-SE (Herraiz et al., 2000). Four moderate-strong historic earthquakes have occurred near the study area (Fig. 1): three earthquakes located in Lorca (80 km away), in 1579, intensity MKS VIII, in 1674 (MKS VIII) and 1818 (MKS VII) and the last one in 1899, MKS IV (Mezcua and Martínez-Solares, 1983). Despite the evidence for moderate to large earthquakes in the paleoseismic and historic record, no large earthquakes have occurred during the instrumental period ( $N$ 1967). Also, there is no clear association be- tween current seismicity and major faults.

This paper focuses on the recent fault activity of the Cordovilla Basin, an elongated NW-SE graben structure that developed from the Late Pleistocene onwards. This basin is part of a major tectonic structure, the Pozohondo Fault, extending throughout the External Betic region of SE Spain (Rodríguez-Pascua et al., 2003). A well-preserved fault surface rupture in the basin was first described by García del Cura et al. (1979). In the present paper, tectonic geomorphology, landscape evolution and fault scarp degradation are described and interpreted in order to: $(A)$ 


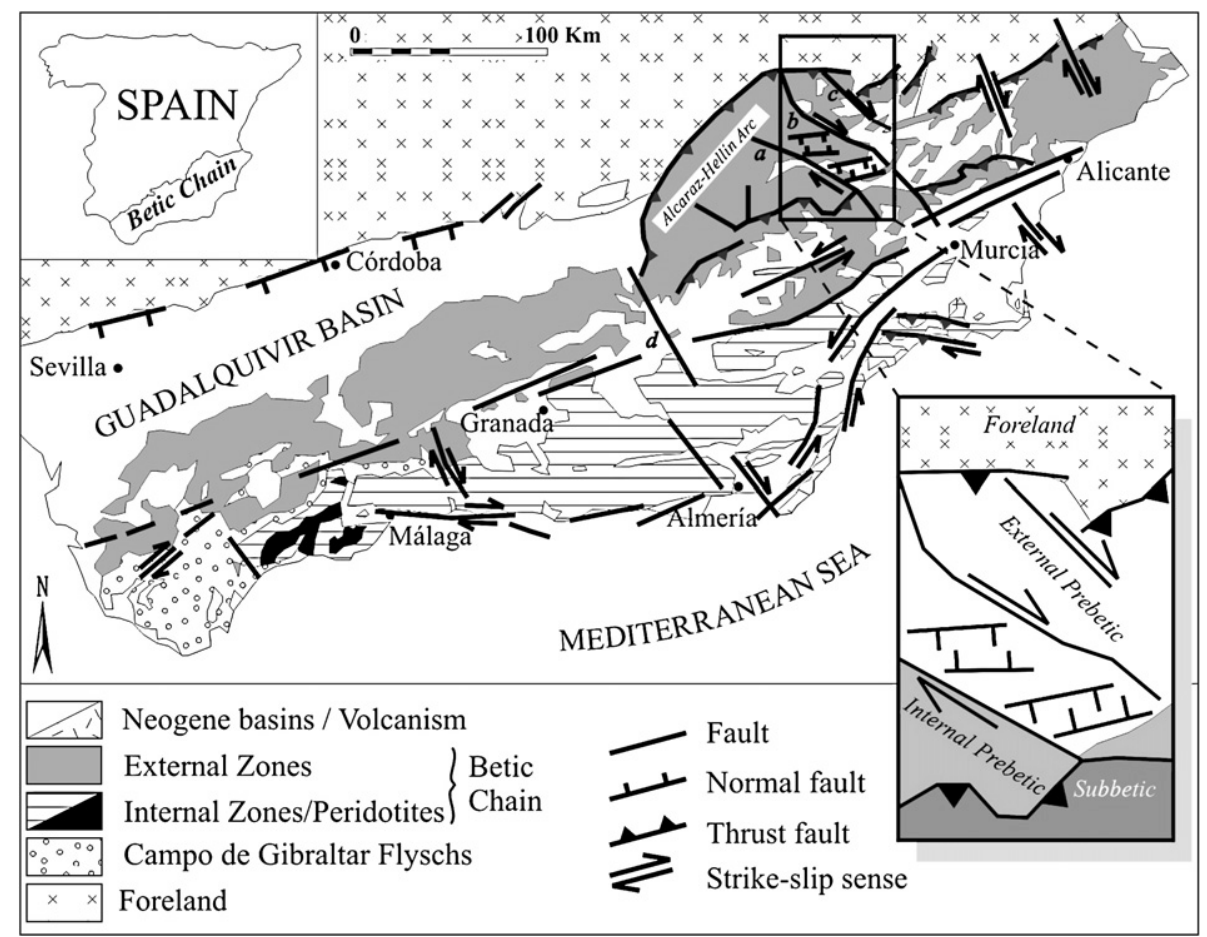

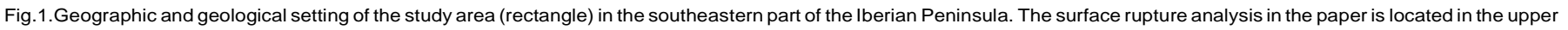
part of the rectangle and relates to the Pozohondo Fault.

estimate the probable age of the more recent fault scarp by the application of the diffusion dating technique (Andrews and Buckman, 1987; McCalpin, 1996), (B) evaluate the probable magnitude of the young earthquake that generated the fault scarp, and (C) infer relation- ships between fault activity and drainage within the basin.

\section{Geological setting}

The Cordovilla Basin is located in the External Prebetic Zone of the Betic Cordillera (Albacete province), in southeast Spain (Jérez-Mir, 1973) (Fig. 1). Major NE to E-W trending thrust structures linked by NW trending dextral strike-slip faults dominated the tectonic framework. In the study area the major structures are the Cazorla-AlcarazHellín thrust (CAH) and the transfer zone formed by the SocovosCalasparra, Lietor and Pozohondo major faults, three main parallel NW-SE trending dextral strike-slip faults (Fig. 2). The CAH thrust was emplaced during the Late Tortonian. Miocene lake basins were developed associated with E-W trending normal faults and have been preserved in structural highs of the block between SocovosCalasparra and Lietor faults (Rodríguez-Pascua et al., 2003). The NE boundary of the transfer zone is defined by the Pozohondo Fault. Here Late Miocene lake basins are poorly developed and topographic relief is low. The geometry and length of all three faults of the transfer zone are similar (Fig. 2), and their kinematics has not varied significantly since the Late Miocene (Rodríguez-Pascua et al., 2003).

The Cordovilla Basin is closely associated to the Pozohondo Fault, a $150 \mathrm{~km}$ long, NW-SE trending active dextral oblique-fault parallel to the Lietor and Socovos-Calasparra faults. The Cordovilla Basin corresponds to a graben with a central horst (Fig. 2). The basin is expressed as a small depression $\left(45 \mathrm{~km}^{2}\right)$ with an irregular boundary, located in a relatively large flat area between Tobarra and Cordovilla ( $38^{\circ} 35^{\prime}$ North Latitude; $1^{\circ} 39^{\prime}$ West Longitude) (Fig. 3). The landscape has low topographic relief and the drainage network is characterised by weakly incised channels running SW to NE. A modern lake, dammed by a linear scarp related to a NW-SE trending normal fault, is present in the southeastern part of the basin.

The Quaternary deposits of the Cordovilla Basin consist mainly of lacustrine and palustrine limestone sediments (freshwater tufa, micritic limestone, calcareous and organic-rich marlstone), siliciclastic deposits, with interbedded gypsum beds and paleosols (García del Cura et al., 1979). This Quaternary fill (with $5 \mathrm{~m}$ of maximum thickness) unconformably overlies Triassic, Jurassic and marine Miocene materials (Fig. 3). García del Cura et al. (1979) differentiated two main geomorphological units within the Cordovilla Basin that they described as "morpho-sedimentary levels", A and B (Fig. 3). These represent Quaternary (Late Pleistocene- Holocene) sedimentary environments within the basin. Level ' $A$ ' corresponds to gypsum deposits widespread within the basin formed in closed-lakes. Level ' $B$ ' is mainly constituted by tufa limestones generated by freshwater channels. Silty alluvial deposits mantling the bottom of the most recent depressions and ponded areas in the basin constitute the rest of the Quaternary fill. Colluvium deposits (Co in Fig. 3) and small alluvial fans are present along the basin margins. From the geometrical relationship between these levels, they appear to be contemporaneous.

Rodríguez-Pascua et al. (2000, 2003), have reported MioceneQuaternary seismic activity associated to the Pozohondo Fault. From current earthquakes, foci location and focal mechanisms, RodríguezPascua and De Vicente (2001) obtained two stress fields characterised by NW-SE and NE-SW orientations of the maximum horizontal stress axis $\left(S_{H \max }\right)$. Similar past seismic activity explains the presence of seismically-induced soft-sediment deformation structures (i.e. seis- mites) in Miocene lake deposits adjacent to this fault. The analysis of earthquake-related structures allowed reconstructing a paleoseis- mic series through the Miocene which displayed a similar " $b$ " value of Gutenberg and Richter empirical law to that obtained from 


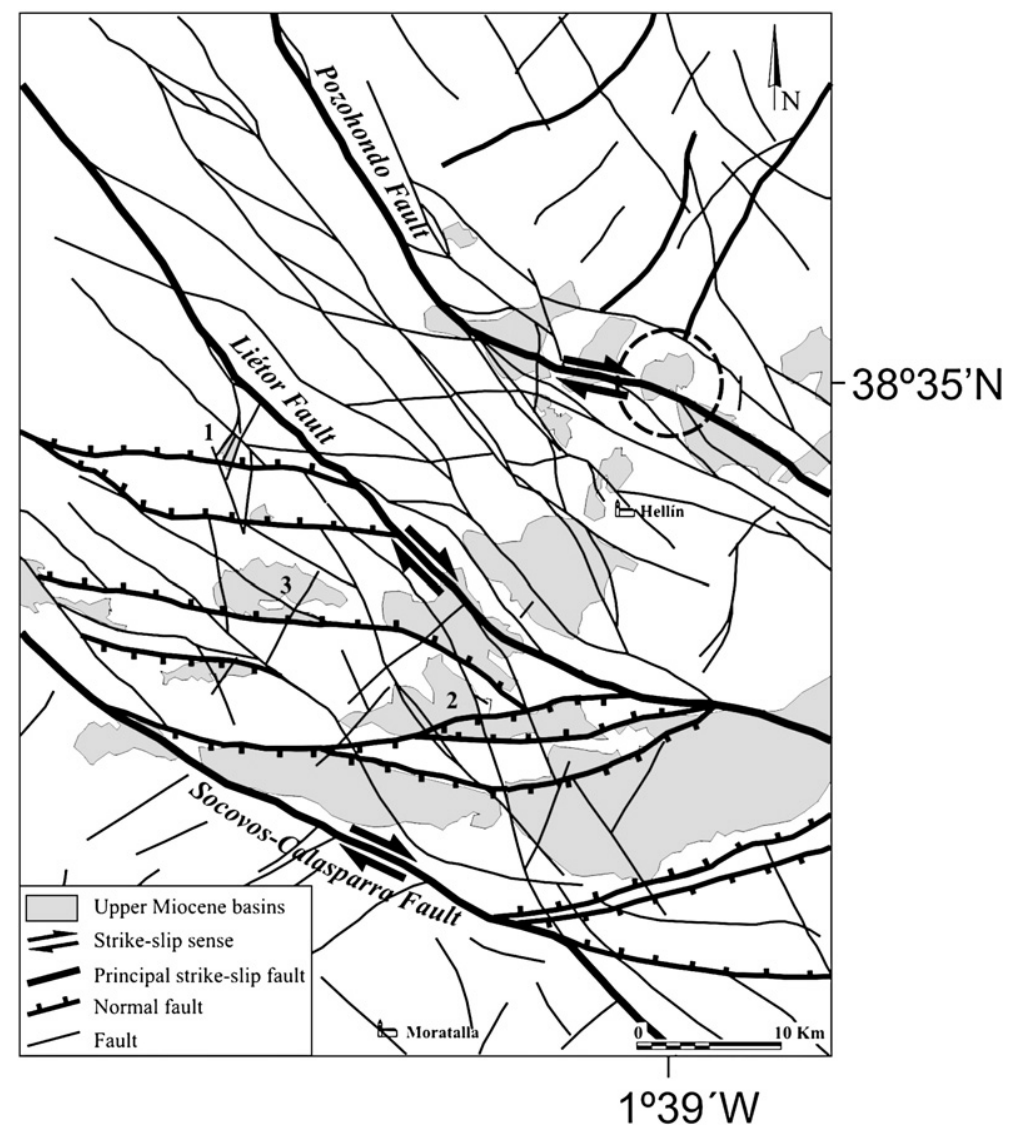

Fig. 2. Main faults of the External Prebetic Zone (black rectangle in Fig. 1.) Three main dextral strike-slip faults are present: Socovos-Calasparra, Lietor and Pozohondo faults. The dashed line encircles the Tobarra-Cordovilla segment of the Pozohondo Fault. (After Rodríguez-Pascua et al., 2003).

the instrumental seismic record (Rodríguez-Pascua et al., 2003). The minimum magnitude $\left(M_{\llcorner}\right)$estimated from the analysis of the fluid- ization was 5.5 .

\section{Active fault mapping and analysis of surface displacement}

In order to investigate the possible recent fault activity and its relation to the surface drainage pattern we have analyzed the fault scarp geometry of the Cordovilla Basin graben. For that, we have reviewed aerial imagery and existing geological maps, length of surface rupture, fault scarp topographic profiles, drainage networks and the origin of modern terminal or sink lakes. Similar studies have been successful in reconstructing the history of recent earthquakes related to fault scarps (McCalpin, 1996, González and Carrizo, 2003). Several NE-SW and NW-SE trending faults cutting the Quaternary deposits of the basin were mapped from air-photo analysis (Fig. 3). The surface ruptures are limited to NW-SE trending faults, bounding tufa sediments and the morphosedimentary levels ' $A$ ' and ' $B$ '. The diffuse drainage network of short streams defines an endorheic basin oriented SW-NE. This closed basin can be related to fault activity due to the presence of graben basins affecting the Qua- ternary filling.

The total surface rupture length (Fig. 4) has been mapped from aerial photo and conventional GPS-supported survey in the field. We mapped 14 discrete active fault traces with a main NW-SE trend. The maximum individual fault length $(333 \mathrm{~m}$ ) corresponds to S1 (Fig. 4) and represents the scarp of the main fault. The maximum surface rupture length of the antithetic fault $(193 \mathrm{~m})$ corresponds to S2 (Fig. 4). The set of surface ruptures delineate a NW-SE oriented graben basin (Fig. 4). A small NW-SE oriented horst structure, (S8 and S10, Fig. 4), appears in the centre of the study area.
A number of well-exposed, fresh fault scarps resulting from earthquake surface rupture can be clearly observed throughout the area studied (Fig. 5). A normal fault scarp and an antithetic fault with SW and NE dips, respectively, control the geomorphic evolution of the area studied. Both scarps displace oncolithic limestone, tufa and marls (Fig. 5). Vertical offsets of the most recent surface ruptures could be determined from preliminary field measurements of cemented soil displacement at the top of the sequence (Fig. $5 \mathrm{a}, \mathrm{b}$ ). The maximum coseismic offsets are 1.9 and $0.6 \mathrm{~m}$ for the main and antithetic faults, respectively (Fig. 5c, d). Other minor traces display offsets as small as a few centimetres. Locally, these scarps show wide fissures, overturned blocks, sinkholes and soil rupture (Fig. 5).

Four detailed topographic profiles oriented NE-SW (see Fig. 4 for location), were carried out to obtain total fault-scarp heights (Fig. 6). The profiles were traced perpendicular to the graben axis and were obtained by using a GPS 3-D receiver with $10 \mathrm{~cm}$ of accuracy. The detailed topographic profiles $\mathrm{P} 1$ and $\mathrm{P} 2$ of the main fault scarp are shown in Fig. 7. The interpretation of profiles P1 and P2 (Fig. 8) has been carried out according to the data requirements for McCalpin's (1996) model (Fig. 6). The value of net throw of the fault $\left(T_{\text {net }}\right)$ ranges between $3.5 \mathrm{~m}$ and $9.5 \mathrm{~m}$, with a vertical displacement of the main fault ranging between 24 and $28 \mathrm{~m}$ (see Figs. 6 and 8). The topographic profile P4 exhibits $6 \mathrm{~m}$ of fault offset for the antithetic fault (Fig. 9). The most reliable topographic control of paleoearthquake activity is derived from presence of a modern small terminal lake dammed by the antithetic fault.

\section{Diffusion equation dating the fault scarp}

The diffusion equation is a stratigraphic technique used to obtain the age of fault scarps (Andrews and Buckman, 1987). The technique is 


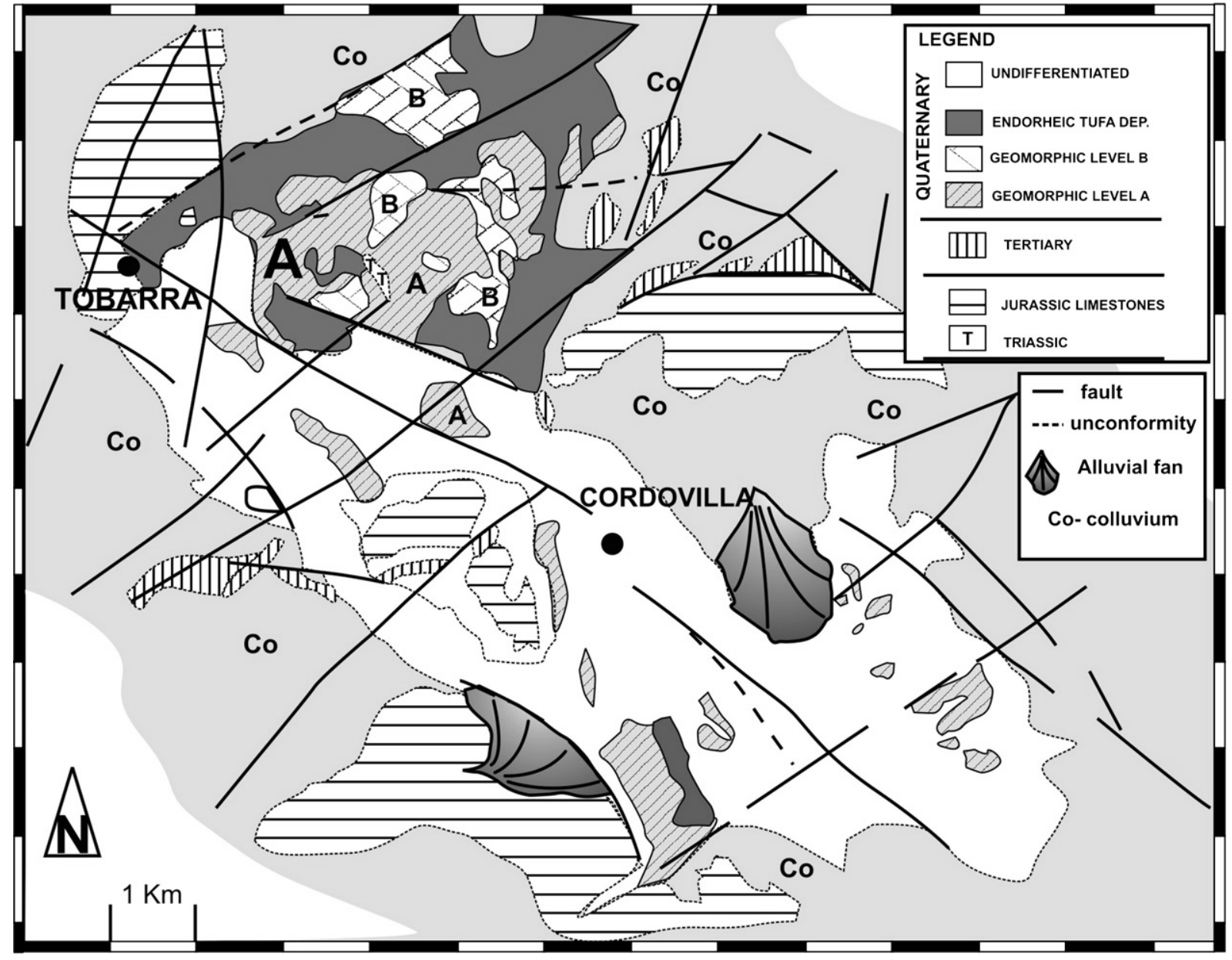

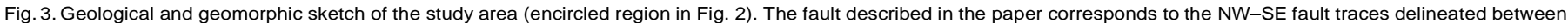
Tobarra and Cordovilla. A and B represent morphosedimentary levels (García del Cura et al., 1979), see text for explanation. (Modified from García del Cura et al., 1979).

simple and takes into account the degradation of a poorly consolidated fault scarp through time. The equation defined by Andrews and Buckman (1987) is:

$t=t^{\prime *}(\mathrm{SO})^{2} / K_{0}$

Where $t$ is time (ka), $t$ ' the dimensionless age constant, SO is the vertical throw of the scarp $(\mathrm{m})$ and $K_{0}\left(\mathrm{ka} / \mathrm{m}^{2}\right)$ is the diffusion constant. The use of the equation has several constraints (McCalpin, 1996; González and Carrizo, 2003). First, the equation can be only applied to non-lithified deposits and normal faults, whether in semigraben or graben basins. In the case of scarps that record multiple events the age is overestimated. Second, if the farfield angle $(\alpha)$ is greater than $10^{\circ}$, or the difference between the maximum scarp angle $(\theta)$ and the far far-field angle $(\alpha)$ is less than $10^{\circ}$, Eq. (1) yields erroneous values (Hanks and Andrews, 1989).

In this paper, the diffusion equation has been applied for profiles P1 and P4 (see Fig. 5 for location). Both scarps satisfy the conditions described above. Profile P1 is performed across the main fault, which cuts unconsolidated sediments comprising marls and soils with non- classified edafic horizons. The area is characterised by low relief, a scarp bounded by cereal cultivation and a poorly developed NE-SW drainage network, with no influence of karstic features.

The diffusion constant ( $K_{0}$ of Eq. (1)) represents a key value needed to calibrate the equation for a particular fault scarp. We have used two $K_{0}$ published values and a new value: $K_{01}=0.46 \mathrm{~m}^{2} / \mathrm{ka}$, minimum value obtained for the Basin and Range Province of western USA,

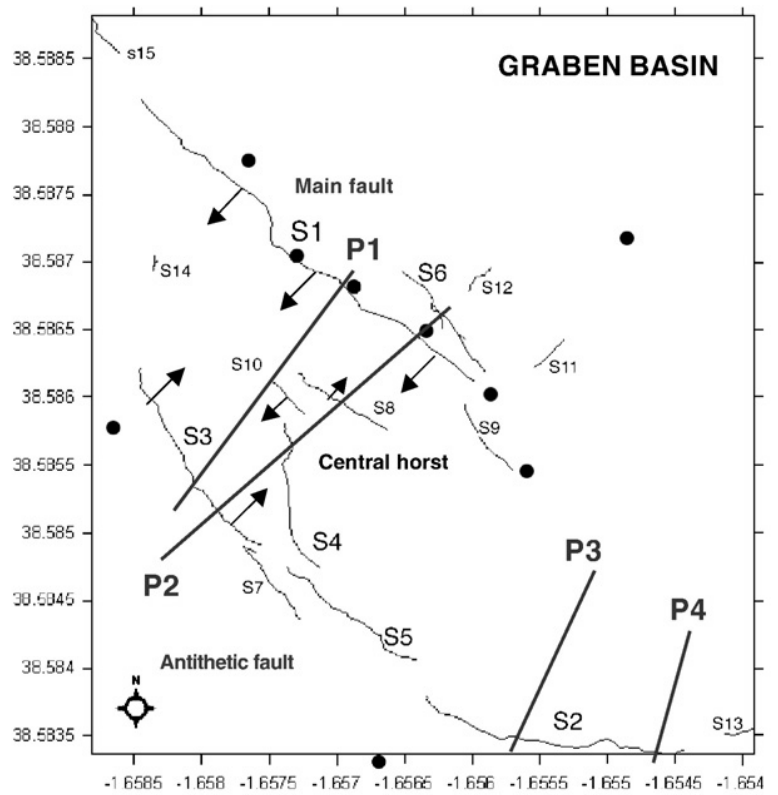

Fig. 4. Sketch map showing recent fault traces (solid lines) measured by GPS. Black dots indicate location of field stations for structural fault measurement, including strike, dip and slickensides. Dashed lines indicate location of detailed topographic profiles. The dammed lake is located at the north end of P3. 


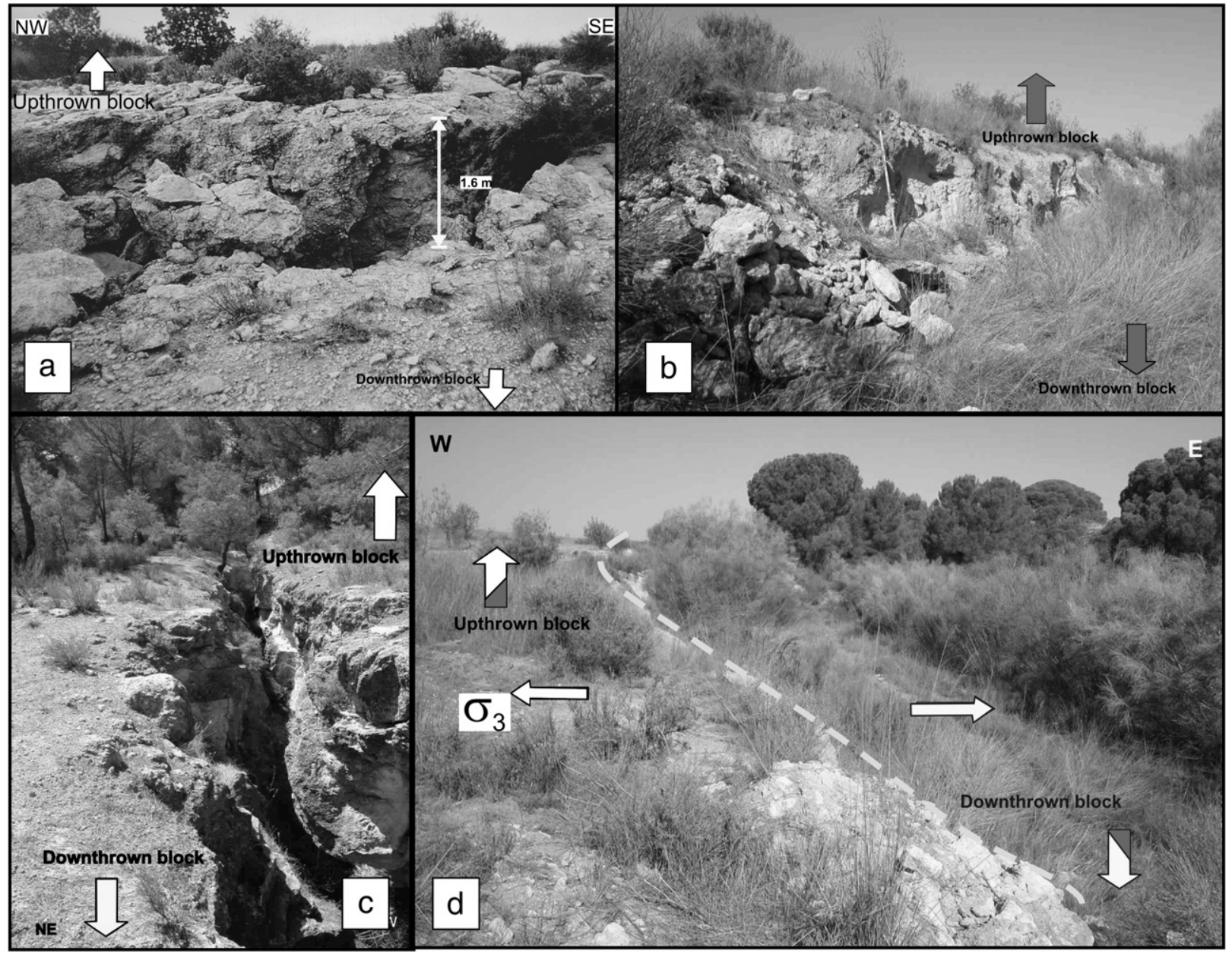

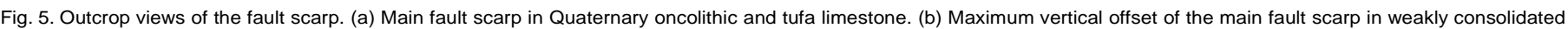

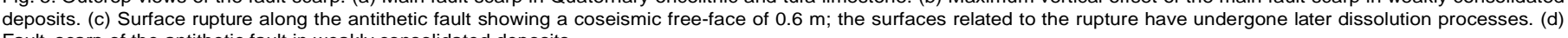
Fault scarp of the antithetic fault in weakly consolidated deposits.

where a semiarid climate prevails (McCalpin, 1996); $K_{02}=0.51$ $\mathrm{m}^{2} / \mathrm{ka}$, maximum value obtained also for the Basin and Range Province (McCalpin, 1996); and $K_{03}$, obtained by using three principal para- meters that modify the fault scarp. These parameters are: (1) the erodability, $K *\left(2.36 \times 10^{6} \mathrm{~kg} / \mathrm{ha}\right.$ per year as mean value for marls with brushwood, Cerdá, 2001); (2) the apparent density of marls ( $\rho_{a}$ $=1.37 \mathrm{~g} / \mathrm{cm}^{3}$; Martínez-Mena et al., 2001); and (3) the scarp vertical throw $(T)$, i.e., the last coseismic free-face, $0.6 \mathrm{~m}$

MAIN FAULT

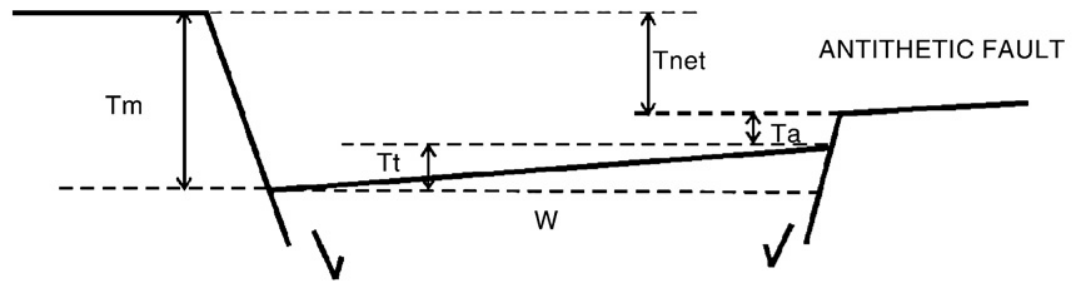

\begin{tabular}{lll}
\multicolumn{1}{c}{ Angular meaurements } & Geometrical measurements & Fault throw measurements \\
\hline$\alpha$ - far-field slope & $\mathbf{H}_{\mathbf{2}}$ - scarp height & Tm- throw of main fault \\
$\beta$ - dip of the fault & SO- surface offset & Tt- throw of back tilting \\
$\theta$ - maximum scarp angle & $\begin{array}{l}\mathbf{H}_{\mathbf{1}} \text { - vertical fault } \\
\text { displacement }\end{array}$ & Ta- throw of antithetic fault \\
& Ns- net fault slip & Tnet- net throw \\
\hline
\end{tabular}


NE
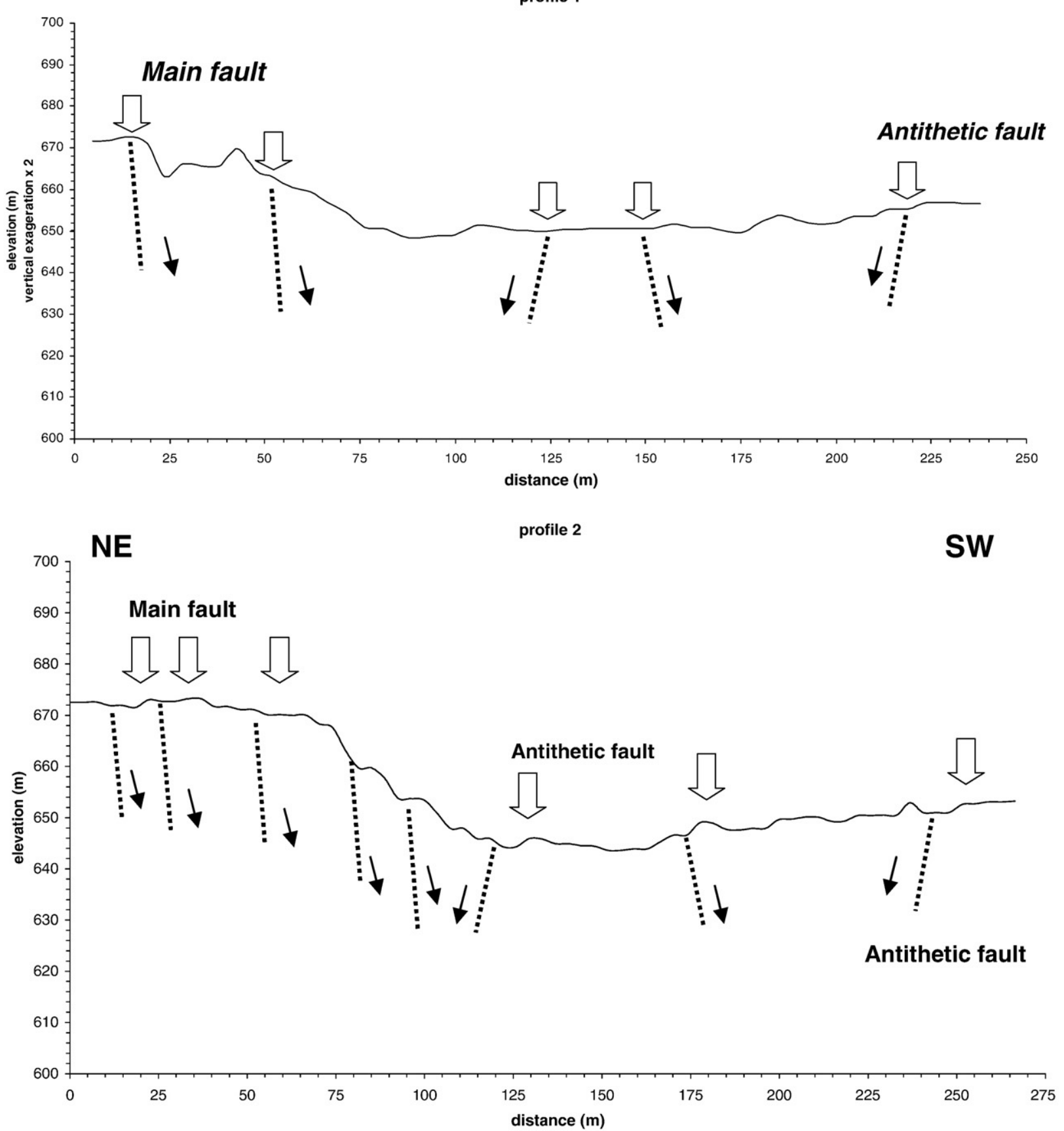

Fig. 7. Topographic profiles P1 and P2 (see Fig. 4 for location). White arrows indicate surface ruptures identified in the field; black arrows indicate the dip-slip sense; dashed lines correspond to idealised fault planes.

According to the values described above, we have introduced the next equation:

$K_{03}=\left(T X K^{*}\right) / \rho_{\mathrm{a}}$

The obtained $K_{03}$ value from Eq. (2) is $0.82 \mathrm{~m}^{2} / \mathrm{ka}$.

Depending on the method, the age of the scarp can range between 1.9 and $1 \mathrm{ka}$ for $\mathrm{P} 1$, and between 2.1 and $1.2 \mathrm{ka}$ for P4 (Table 1). Values from the Basin and Range Province $\left(K_{01}\right.$ and $\left.K_{03}\right)$ are realistic, although the annual average rainfall in the study area (355 mm during the period 1991-2000) is higher than in western
USA (below $254 \mathrm{~mm}$ during the same period). Therefore, we propose that the younger age of the coseismic offset of fault scarp ranges between 1.7 and $1 \mathrm{ka}$ for the main fault and between 1.9 and 1.2 $\mathrm{ka}$ for the antithetic fault. The value obtained from the diffusion equation will only correspond to the last coseismic offset observed on the fault scarp.

\section{Estimation of the maximum magnitude}

We have used empirical relationship of Wells and Coppersmith (1994) to estimate the maximum magnitude of the most recent earthquake 


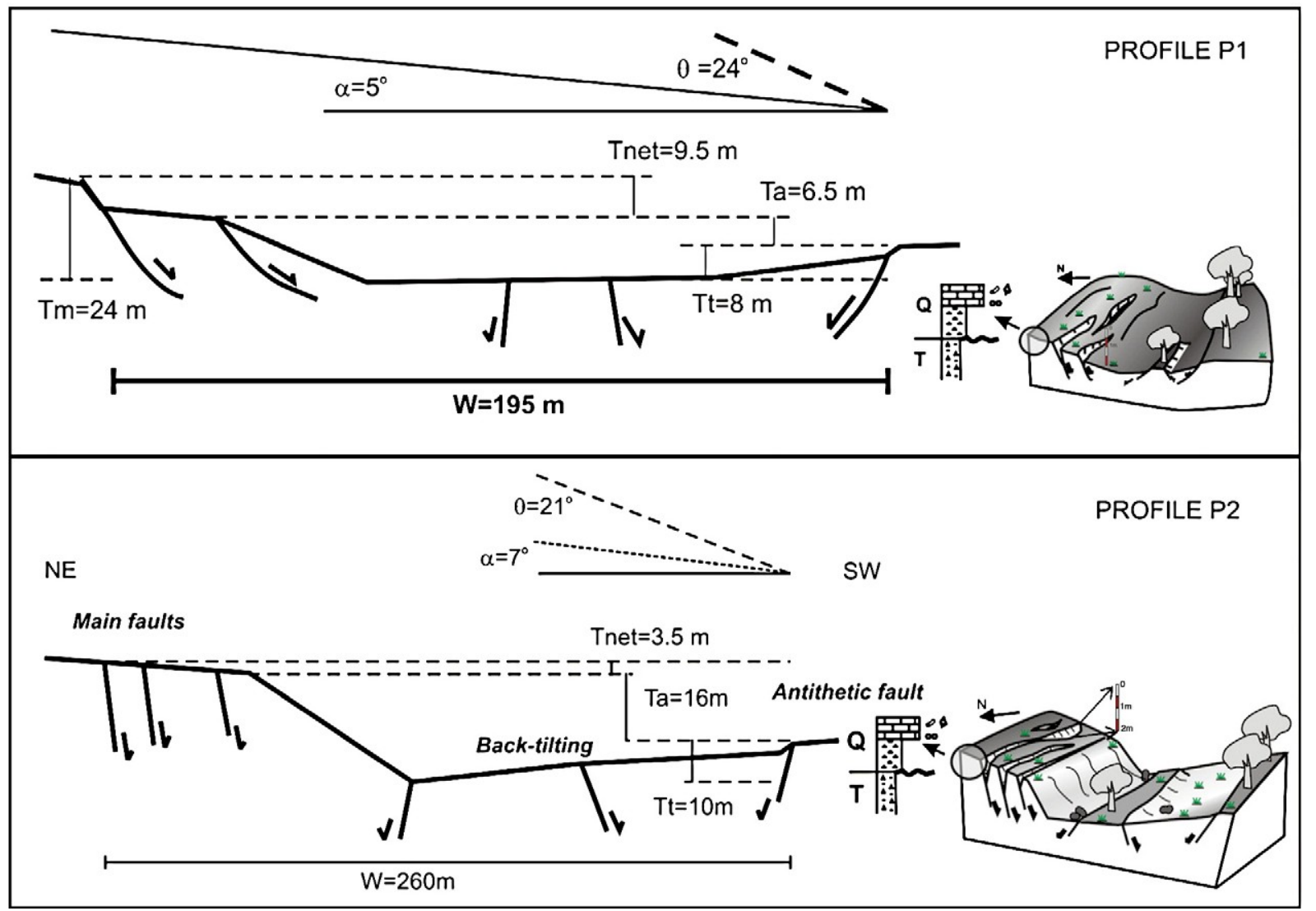

Fig. 8. Geometric reconstruction of topographic profiles $\mathrm{P} 1$ and $\mathrm{P} 2$ based on geometric and angular parameters shown in Fig. 6. Block diagrams represent extrapolated 3-D reconstructions of the areas adjacent to the profiles (Q: Quaternary; T: Triassic).

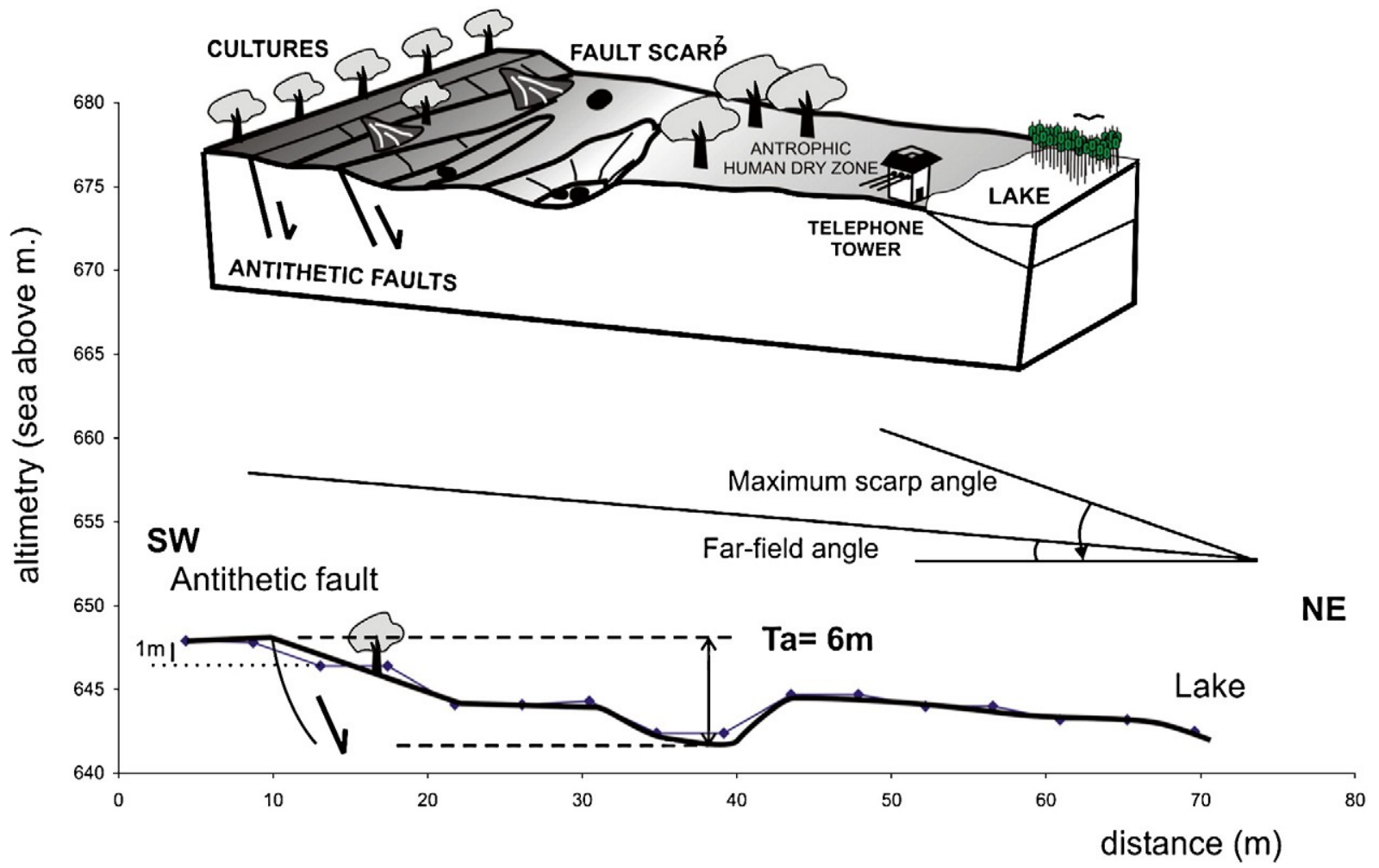

Fig. 9. Topographic profile P4 (see Fig. 4 for location). The profile shows the antithetic fault scarp as well as the geometric and angular measurements. The 3-D reconstruction sketch of the area adjacent to profile P4 is shown in the block diagram. 
Table 1

Age of the fault scarp based on the diffusion equation for the main and antithetic faults (see meaning of the symbols: $\alpha, \theta$, SO, and $K_{0}$ in Fig. 6 )

\begin{tabular}{lllllll}
\hline Profile & Fault & $\alpha\left({ }^{\circ}\right)$ & $\theta$ & SO $(\mathrm{m})$ & $K_{0}\left(\mathrm{~m}^{2} / \mathrm{ka}\right)$ & Age (years) \\
\hline P1 & Main & 5 & $24^{\circ}$ & 2.5 & 0.46 & 1933 \\
& & & & 0.51 & 1744 \\
& & & & 0.82 & 1084 \\
P2 & Antithetic & \multirow{2}{*}{5} & \multirow{2}{*}{19} & \multirow{2}{*}{$* 4$} & 0.46 & 2102 \\
& & & & & 0.51 & 1896 \\
& & & & & 0.82 & 1179 \\
\hline
\end{tabular}

within the Cordovilla Basin from surface fault length and coseismic displacement. Wells and Coppersmith's (1994) equations are:

$\mathrm{Mw}=4.86+1.32 * \log (\mathrm{SRL})$

$\mathrm{Mw}=6.61+0,71^{*} \log (\mathrm{MD})$

$\mathrm{Mw}=6.78+0,65^{*} \log (\mathrm{AD})$

Where the SRL value represents the surface rupture length in $\mathrm{km}, \mathrm{MD}$ is the maximum vertical displacement $(m)$ and $A D$ is the average vertical displacement $(\mathrm{m})$ of the normal fault.

In order to get the most realistic fault surface rupture length, the following information has been used: (a) geological mapping from García del Cura et al. (1979); (b) field GPS measurements of the total length of the Tobarra-Cordovilla segment; (c) scarp interpretation using aerial imagery (Fig. 10); (d) morpholineaments interpreted from panchromatic orthoimage 3-D LANDSAT 7 (ETM)+ DEM (30 $\times 30 \mathrm{~m}$ of pixel size); and (e) length of the Pozohondo fault mapped by Rodríguez-Pascua et al. (2003). Magnitude (Mw) estimation results range between 5.1 and 7.2 and are summarized in Table 2. We regard these results as maximum values because we have not attempted a segmentation of the fault.
Table 2

Estimation of earthquake size from the surface rupture length

\begin{tabular}{|c|c|c|c|c|c|c|c|c|c|}
\hline \multicolumn{2}{|c|}{$\begin{array}{l}\text { García del Cura } \\
\text { et al. (1979) }\end{array}$} & \multicolumn{2}{|l|}{ Field GPS } & \multicolumn{2}{|c|}{$\begin{array}{l}\text { Aerial } \\
\text { orthophoto }\end{array}$} & \multicolumn{2}{|c|}{$\begin{array}{l}\text { Ortho-Landsat } \\
7\end{array}$} & \multicolumn{2}{|c|}{$\begin{array}{l}\text { Rodríguez- } \\
\text { Pascua et al. } \\
\text { (2003) }\end{array}$} \\
\hline SRL $(\mathrm{km})$ & Mw & SRL (km) & Mw & SRL (km) & Mw & SRL (km) & Mw & SRL (km) & Mw \\
\hline \multirow[t]{2}{*}{8} & 6.1 & 1.5 & 5.1 & 4.7 & 5.7 & 9.3 & 6.1 & 55 & 7.2 \\
\hline & & & & 1.93 & 5.2 & 11 & 6.2 & & \\
\hline
\end{tabular}

The moment magnitude has been obtained from Eq. (3) (see text).

We have also estimated Mw from coseismic displacement (Eqs. (4) and (5)). For this purpose, the fault throw value was determined from: (a) direct measure of the apparent coseismic offset and (b) topographic detailed profiles (P1, P2, P4) (Figs. 8 and 9). However, the throw of the main fault $\left(T_{\text {net }}\right)$ could have resulted from the accumulation of multiple events, and therefore, we consider these values preliminary until more detailed paleoseismic studies are undertaken (Table 3). Bearing this in mind, the earthquake magnitudes have been estimated for several possible cases. Mw estimates from coseismic displacement range be- tween 6.3 as minimum value and 7.3 as the maximum value.

\section{Discussion}

Fault geometry and its relationships to different morphotectonic blocks along the Pozohondo Fault suggest possible fault segmentation. Geomorphological evidence indicates that the Tobarra-Cordovilla segment is an active graben basin with complex normal fault scarp geometry. Fault traces show both large eroded scarps representing accumulated fault movement, as well as coseismic free free-face, the latter being related to the most recent event.

Landform evolution was controlled by fault activity, as evidenced by the presence of dammed lakes. The upthrown block of the antithetic fault, recording the younger tectonic Holocene activity, dams the nearby lake. The graben basin consists of an endorheic basin with a poorly defined

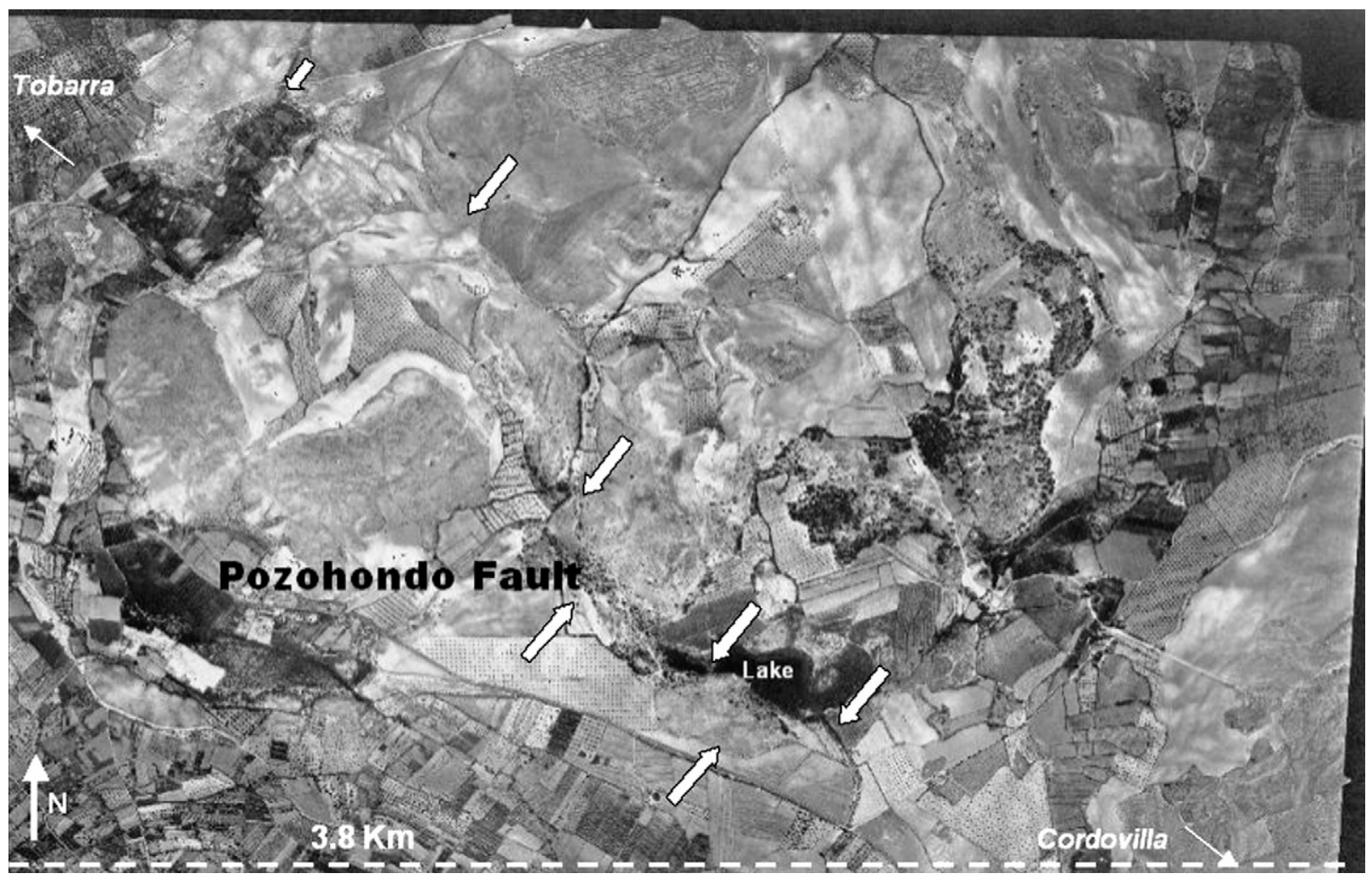

Fig. 10. Aerial orthophotograph of the Tobarra-Cordovilla fault segment. White arrows indicate the fault scarp showing a total segment rupture length of about $4.5 \mathrm{~km}$. The orthophotography has been obtained from ASTER DEM with a $30 \times 30$ pixel size. 
Table 3

Estimation of earthquake size from the maximum and average fault throw

\begin{tabular}{|c|c|c|c|c|c|c|c|c|c|}
\hline \multicolumn{2}{|l|}{ P1 } & \multirow{2}{*}{$\begin{array}{l}\mathrm{P} 2 \\
T_{\text {net }}(\mathrm{m})\end{array}$} & \multirow[b]{2}{*}{$\mathrm{Mw}$} & \multirow{2}{*}{$\begin{array}{l}\text { P4 } \\
\text { SO (m) }\end{array}$} & \multirow[b]{2}{*}{ Mw } & \multicolumn{4}{|c|}{ Field data } \\
\hline$T_{\text {net }}(\mathrm{m})$ & $\mathrm{Mw}$ & & & & & $\mathrm{MD}(\mathrm{m})$ & Mw & $A D(m)$ & Mw \\
\hline 9.5 & 7.3 & 3.5 & 7.0 & 1.4 & 6.7 & 1.9 & 6.8 & 0.7 & 6.7 \\
\hline 3.5 & 7.0 & & & & & $0.6 *$ & 6.4 & & \\
\hline & & & & & & $0.4 * *$ & 6.3 & & \\
\hline
\end{tabular}

Mw has been obtained from Eqs. (4) and (5); asterisk indicates values for the coseismic free-face determined from fieldwork in the antithetic fault.

drainage network. Tufa and oncolithic limestone associated with the fault scarp indicate that there have been long-lived tectonic terminal lakes here since the Pliocene (García del Cura et al., 1979). The fresh fault scarp is explained either by recent fault activity or by a low rate of erosion, in response to the semiarid climate affecting the study area.

The application of Wells and Coppersmith (1994) empirical relationships indicates that earthquake magnitude (Mw) can range between 5.1 and 7.3 (Tables 2,3). The $\mathrm{Mw}$ values derived from fault length can be influenced by land use. Mw values determined from the total cartographic length of the Pozohondo Fault (Rodríguez-Pascua et al., 2003) are very high as the fault might rupture in segments. Therefore, we assume that a more realistic fault rupture length is obtained from either Landsat 7 mapping or the map performed by García del Cura et al. (1979). In both cases, the value of Mw is higher or equal than 6.1 (Table 2).

Mw derived from fault offset has also large uncertainties (Table 3). Mw values obtained from topographic profiles P1, P2 and P4 are probably overestimated (up to $\mathrm{Mw}$ 7.3) since the scarp resulted from the added effect of multiple events. However, the Mw value estimated for the free-face height $(0.6 \mathrm{~m})$ determines a minimum value of 6.3 (Table 3). Although this value agrees with the $\mathrm{Mw}$ value calculated above for the surface rupture length (Table 2), it is unclear if several fault traces can rupture in the same event, so that total coseismic displacement has to be added across these faults.

Nevertheless, the graben morphology of the Tobarra-Cordovilla segment suggests the occurrence of events with greater magnitude, based on stepped and overturned blocks similar to the Burbanks earthquake, Alaska 1964, where a Mw 8.6 was determined (Bolt, 1999). We suggest that the Tobarra-Cordovilla segment corresponds with a graben basin with backtilting, the geometry of which can be the result of an exaggerated land response due to an amplification of the earthquake by shaking (Hanks and Andrews, 1989).

Based on our estimate of the age of the fault scarp, we propose that the youngest event could be dated between 1000 and 2000 years B.P. As the scarp height yields a maximum value of $1.9 \mathrm{~m}$, three similar previous earthquakes with $\mathrm{Mw}$ of 6.3 (with individual coseismic offset of $0.6 \mathrm{~m}$ ), can be postulated. This can be extrapolated to the cumu- lative effect vertical offset of the main fault of $24 \mathrm{~m}(\mathrm{Tm})$ (Fig. 8). In that case, almost 40 events of such magnitude would have been required to configure the present landscape. However, more accurate evidence is needed, such as absolute dating and trenching to obtain more robust estimate of coseismic displacement.

According to recent proposals for active fault classification dealing with earthquake magnitude-frequency as a function of the geomorphological evidence (Michetti et al., 2005), the Tobarra-Cordovilla segment classifies the Pozohondo Fault as type B. This fault exhibits moderate activity with well-developed geomorphic evidence of activity.

Finally, similarities among Pozohondo, Socovos-Calasparra and Lietor faults suggest the possibility that the last faults could be actives also. These similarities include fault geometry, trend, length, age, character and tectonic framework.

\section{Conclusions}

The geomorphic analysis of the Cordovilla Quaternary Graben reveals the occurrence of historic surface faulting events (ca.1-2 ka B.P.) controlling and modifying the intrabasinal drainage at relatively short timescales. From the seismological point of view the paleoseismological data described in this work increased the seismic record of a zone (Prebetic Zone) with scarce instrumental and historical seismicity. The newly obtained data, such as the size and age of the most recent paleoearthquake, can be incorporated into further hazard analysis.

Fault scarps of this graben have been the consequence of multiple Quaternary events. The present landscape exhibits dammed lakes and a diffuse NE-SW drainage network, which is strongly controlled by the normal-oblique activity of the Pozohondo Fault. The graben basin is bounded by active NW-SE striking faults (main and antithetic character), with a small central horst. The present graben morphology appears to have resulted from complex fault activity with associated backtilting.

We have applied the diffusion equation to assess possible age of the fault scarp. In order to obtain a more realistic value, we have introduced Eq. (2) to estimate the diffusion constant $K_{0}$ of this area. This equation is defined as the relationship among the fault offset $(T)$ measured on the coseismic free-face, the density of the affected sediments $\left(\rho_{\mathrm{a}}\right)$ and the theoretical erodability value $(K *)$. An age ranging between 2 and 1 ka has been determined. We propose this is a possible age for the most recent event.

The moment magnitude Mw value was estimated from the Wells and Coppersmith's (1994) empirical relationships for normal faults. Because on uncertainties associated with estimating fault rupture length and coseismic displacement, we have used those different equations and several alternative fault parameter values. Our best estimate is that the Mw value is greater than 6.1. For this reason, more detailed work on active faults in the Albacete province is needed in order to incorporate paleoseismic evidence into future hazard analyses. All these analyses indicate that Pozohondo is an active fault with segmentation and probably, both Socovos-Calasparra and Lietor are active faults as well.

\section{Acknowledgements}

We thank Dr. Pablo Silva, Dr. Christian Beck, Dr. Franck Audemard and Dr. Adrian Harvey for their fruitful remarks and suggestions. We are also grateful to Dr. Pilar Villamor (GNS New Zealand) for his linguistic assistance. Thanks are given to Dr. Gerardo de Vicente for his scientific advice and to Delfín Martínez Muñoz for technical support. This work was supported by the Spanish ministerial project ACTISIS, CGL2006-05001/BTE.

\section{References}

Andrews, D.J., Buckman, R.C., 1987. Fitting degradation of shoreline scarps by a model with nonlinear diffusion. J. Geophys. Res. 92, 12,857-12,867.

Bolt, B.A., 1999. Earthquakes. Freeman and Company, New York. 136 pp.

Calvo, J.P Rodríguez-Pascua, M.A., Martín-Velázquez, S., Ximénez, S., De Vicente, G., 1998. Microdeformation of lacustrine laminite sequences. An interpretation of loop-bedding. Sedimentology 45, 279-292.

Carreño, E., Martínez-Solares, M., Sanchéz-Venero, M., Bufforn, E., Herraiz, M., Udías, A., Gallart, J., Cisternas, A., Rivera, L.A., Gaulon, J., Patau, G., Phillip, H., 1989. Microseismicity surveys of the fault-systems of SE Spain. Rev. Geofís. 45, 117122.

Cerdá, A., 2001. La erosión del suelo y sus tasas en España. Ecosistemas 3, 1-16. García del Cura, M.A., Ordóñez, S., Calvo, J.P., 1979. Estudio sedimentológico de la cuenca cuaternaria de Cordovilla (Provincia de Albacete). Actas de la III Reunión Nacional del Grupo Español de Trabajo del Cuaternario, Zaragoza, CSIC, pp. 247-257.

González, G., Carrizo, D., 2003. Segmentación, cinemática y cronología relativa de la deformación tardía de la Falla Salar del Carmen, Sistema de Fallas de Atacama, $\left(23^{\circ} 40^{\prime}\right.$ S), norte de Chile. Rev. Geol. Chile 30, 223-244.

Hanks, T.C., Andrews, D.J., 1989. Effect of far-field slope on morphologic dating of scarplike landforms. J. Geophys. Res. 94, 565-573.

Herraiz, M., De Vicente, G., Lindo-Ñaupari, R., Giner-Robles, J.L., Simón, J.L., González- Casado, J.M., Vadillo, O., Rodríguez-Pascua, M.A., Cicuéndez, J.I., Gonzâlez- Casado, J.M., Vadillo, O., Rodríguez-Pascua, M.A., Cicuéndez, J.I., new perspective about the recent (Upper Miocene to Quaternary) and present new perspective about the recent (Upper Miocene to Quaternary) and presen
tectonic stress distributions in the Iberian Peninsula. Tectonics 19,762-786. tectonic stress distributions in the Iberian Peninsula. Tectonics 19, 762-786.
Jérez-Mir, L. 1973. Geología de la zona Prebética en la transversal de Elche de la Sierra y sectores adyacentes (provs. De Albacete y Murcia). Ph. D. Thesis, Universidad de Granada. 
Martínez-Díaz, J.J., 1999. Sismotectónica de la Falla de Alhama de Murcia: implicaciones sismogenéticas del Terremoto de Lorca de Junio, $1977\left(M_{b}: 4,2\right)$ Estud. Geol. 55, 251-266.

Martínez-Díaz, J.J., Masana, E., Hernández-Enrile, J.L., Santanach, P., 2003. Effects of repeated palaeoearthquakes on the Alhama de Murcia Fault (Betic Cordillera, Spain) on the Quaternary evolution of an alluvial fan system. Ann. Geophys. 46, 775-792.

Martínez-Mena, M., Abadía, R., Castillo, V., Albaladejo, J., 2001. Experimental design with a rainfall simulator to study the erosion changes within storm. design with a rainfall simulator
Cuatern. Geomorfol. 15, 30-43.

Masana, E., 1996. Evidence for past earthquakes in an area of low historical seismicity: the Catalan coastal ranges, NE Spain. Ann. Geofis. 39, 689-704.

Masana, E., Pallás, R., Perea, H., Ortuño, M., Martínez-Díaz, J.J., García-Meléndez, E., Santanach, P., 2005. Large Holocene morphogenic earthquakes along the Albox fault, Betic Cordillera, Spain. J. Geodyn. 40, 119-133.

McCalpin, J., 1996. Paleoseismology. Academic Press, San Diego. 588 pp.

Mezcua, J., Martínez-Solares, J.M., 1983. Sismicidad del Área Ibero-Magrebí. Instituto Geográfico Nacional. publicación n²03, 299 pp.

Michetti, A.M., Audemard, F.A.M., Marco, S., 2005. Future trends in paleoseismology: integrated study of the seismic landscape as a vital tool in seismic hazard analyses. Tectonophysics 408, 3-21.

Rodríguez-Pascua, M.A., De Vicente, G., 2001. Estado de esfuerzos actual en la Cordillera Bética Oriental. Bol. Geol. Min. de España 112, 79-95.

Rodríguez-Pascua, M.A., Calvo, J.P., De Vicente, G., Gómez-Gras, D., 2000. Softsediment deformation structures interpreted as seismites in lacustrine sediments of the Prebetic Zone, SE Spain, and their potential use as indicators of earthquakes magnitudes during the Late Miocene. Sediment. Geol. 135, 117-135.
Rodríguez-Pascua, M.A., De Vicente, G., Calvo, J.P., Pérez-López, R., 2003. Similarities between recent seismic activity and paleoseismites during the Late Miocene in the External Betic Chain: relationship by "b" value and fractal dimension. J. Struct. Geol. 25, 749-763.

Santanach, P., Masana, E., 1999. Paleosesismicity in a Low Seismicity Area: the Case of Spain. Proceedings of the 2nd EU-Japan Workshop on Seismic Risk, pp. 3647.

Silva, P.G., Harvey, A.M., Zazo, C., Goy, J.L., 1992. Geomorphology, depositional style and morphometric relationships of Quaternary alluvial fans in the Guadalentin Depression (Murcia, SE Spain). Zeits. fur Geomorph. 36, 325-357.

Silva, P.G., Goy, J.L., Somoza, L., Zazo, C., Bardají, T., 1993. Landscape response to strike- slip faulting linked to collisional settings: Quaternary tectonics and basin formation in the Eastern Betics, Southeast Spain. Tectonophysics 224, 289 303.

Silva, P.G., Goy, J.L., Zazo, C., Lario, J., Bardají, T., 1997. Palaeoseismic indications along "aseismic" fault segments in the Guadalentín Depression (SE Spain). J. Geody- namics 24, 105-115.

Silva, P.G., Goy, J.L., Zazo, C., Bardají, T., 2003. Fault-generated mountain fronts in southeast Spain: geomorphologic assessment of tectonic and seismic activity. Geomorphology 50, 203-225.

Stich, D., Ammon, C.J., Morales, J., 2003. Moment tensor solutions for small and moderate earthquakes in the Ibero-Maghreb region. J. Geophys. Res. 108, 2148. doi:10.1029/2002JB002057.

Wells, D.L., Coppersmith, K.J., 1994. New empirical relationships among magnitude, rupture length, rupture width, rupture area, and surface displacement. Bull. Seismol. Soc. Am. 84, 974-1002. 